\title{
Fenestration of the internal carotid artery mimicking floating thrombus on CT and MR angiography
}

Figure Vascular imaging of the left internal carotid artery

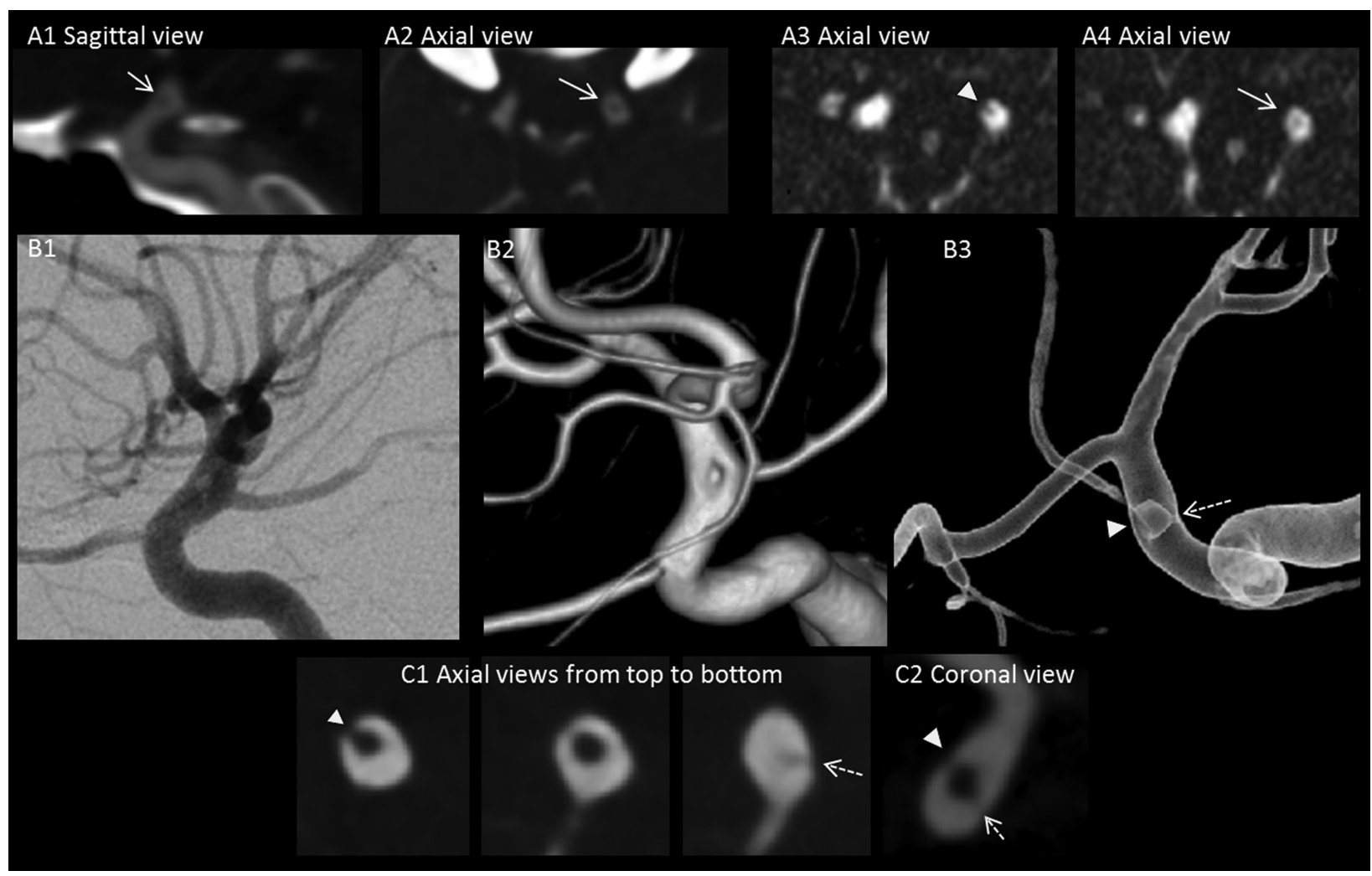

$C T$ angiography $(A, 1-2)$ and magnetic resonance angiography $(A, 3-4)$ showed a defect within the left internal carotid artery connecting the internal wall (arrowhead). Three-dimensional rotational angiography with reconstructions (B: digital subtraction angiogram in 1 and volume rendered images in 2 and 3 ) and derived cross-sections (C: axial views in 1 and coronal view in 2) demonstrated a typical fenestration with a wide separation on the internal side (arrowheads) that became very narrow on the opposite side (dotted arrows).

A 19-year-old woman presented with transient right sensory-motor deficit following headache. Brain MRI was normal but magnetic resonance angiography and CT angiography showed an endoluminal defect within the left internal carotid artery (ICA) that was interpreted as a floating thrombus (figure, A). Threedimensional rotational angiography demonstrated a short ICA fenestration, ${ }^{1}$ an incidental finding in an atypical migraine attack (figure, B and C). Fenestration refers to segmental duplication of the lumen into 2 distinct channels. While well-known on anterior communicating or basilar arteries, fenestrations of the supraclinoid ICA are rare and diagnosis can be difficult on cross-sectional images. ${ }^{2}$

Thomas Tourdias, MD, Jerome Berge, MD, Patrice Menegon, MD, Igor Sibon, MD, PhD, Bordeaux, France Disclosure: The authors report no disclosures.

Address correspondence and reprint requests to Dr. Thomas Tourdias, Université Victor Segalen Bordeaux 2, CHU de Bordeaux, Service de NeuroImagerie Diagnostique et Thérapeutique, Place Amélie Raba-Léon, Bordeaux, F-33076, France; thomas.tourdias@chu-bordeaux.fr

\section{REFERENCES}

1. van Rooij SB, van Rooij WJ, Sluzewski M, Sprengers ME. Fenestrations of intracranial arteries detected with 3D rotational angiography. AJNR Am J Neuroradiol 2009;30:1347-1350.

2. Bharatha A, Aviv RI, White J, Fox AJ, Symons SP. Intracranial arterial fenestrations: frequency on CT angiography and association with other vascular lesions. Surg Radiol Anat 2008;30:397-401. 


\section{Neurology}

\section{Fenestration of the internal carotid artery mimicking floating thrombus on CT and MR angiography}

Thomas Tourdias, Jerome Berge, Patrice Menegon, et al.

Neurology 2011;76;1846

DOI 10.1212/WNL.0b013e31821ccd28

\section{This information is current as of May 23, 2011}

\section{Updated Information \& Services}

References

Subspecialty Collections

Permissions \& Licensing

Reprints including high resolution figures, can be found at: http://n.neurology.org/content/76/21/1846.full

This article cites 2 articles, 1 of which you can access for free at: http://n.neurology.org/content/76/21/1846.full\#ref-list-1

This article, along with others on similar topics, appears in the following collection(s):

CT

http://n.neurology.org/cgi/collection/ct

MRI

http://n.neurology.org/cgi/collection/mri

Information about reproducing this article in parts (figures,tables) or in its entirety can be found online at:

http://www.neurology.org/about/about_the_journal\#permissions

Information about ordering reprints can be found online:

http://n.neurology.org/subscribers/advertise

Neurology ${ }^{\circledR}$ is the official journal of the American Academy of Neurology. Published continuously since 1951, it is now a weekly with 48 issues per year. Copyright Copyright $@ 2011$ by AAN Enterprises, Inc.. All rights reserved. Print ISSN: 0028-3878. Online ISSN: 1526-632X.

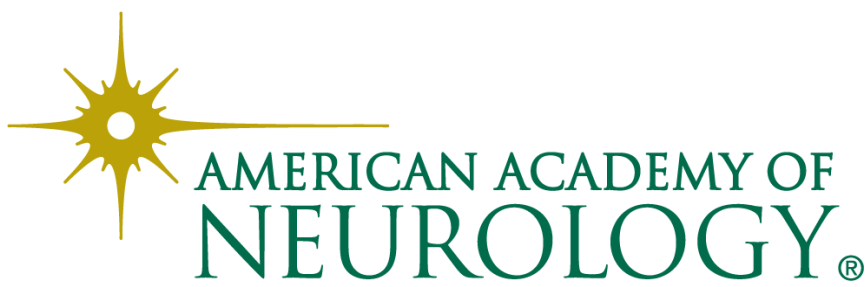

